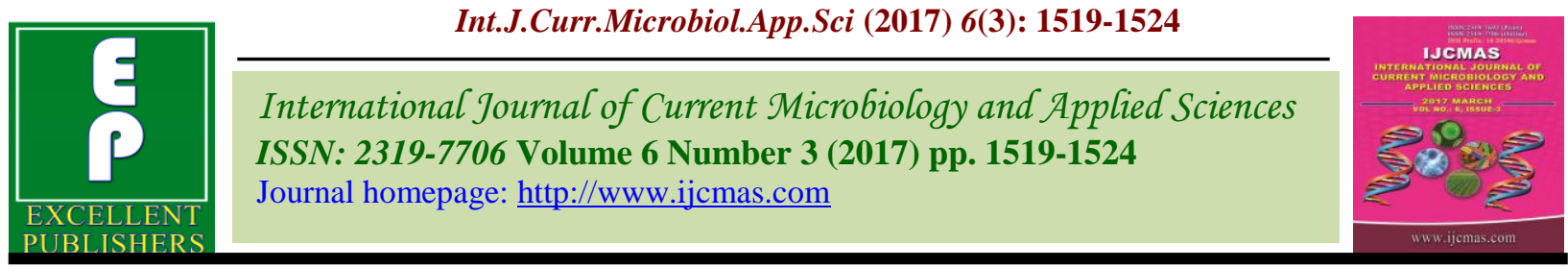

Original Research Article https://doi.org/10.20546/ijcmas.2017.603.174

\title{
Seasonal Variations in Bacterial Community Composition in Tapi River, Surat, Gujarat, India
}

\author{
Kinjal Sangani* and Kapila Manoj \\ Department of Aquatic Biology, Veer Narmad South Gujarat University, Surat, Gujarat, India \\ *Corresponding author
}

\begin{tabular}{|c|c|}
\hline & A B S T R A C T \\
\hline $\begin{array}{l}\text { Ke y w or d s } \\
\text { Tapi River, } \\
\text { Freshwater, } \\
\text { Seasonal variation, } \\
\text { Bacterial } \\
\text { community, } \\
\text { Biodiversity. }\end{array}$ & \multirow{3}{*}{$\begin{array}{l}\text { The purpose of this study was to assess seasonal variations in bacterial community } \\
\text { composition in Tapi River. Samples from three selected sites along the Tapi River stretch } \\
\text { were collected and analyzed for various physico-chemical properties as well as microbial } \\
\text { load and composition of bacterial communities. The number of total viable counts as well } \\
\text { as bacterial isolation and identification were done by using Bergey's Manual of } \\
\text { Determinative Bacteriology. Observations revealed that Gammaproteobacteria was } \\
\text { dominating the community in bacterial assemblage followed by Cyanobacteria, } \\
\text { Firmicutes, Actinobacteria and Bacteroidetes. During summer season diverse bacterial } \\
\text { genera were observed with higher bacterial load, while in winter, diversity was poor with } \\
\text { relatively lower bacterial load. Comparatively lower bacterial load and less genera } \\
\text { diversity was reported during monsoon. The most frequently found bacterial isolate was } \\
\text { Pseudomonas and the least abundant bacteria were Flavobacterium. It was also observed } \\
\text { that concentrations of nutrients play their role to determine the community composition. }\end{array}$} \\
\hline Article Info & \\
\hline $\begin{array}{l}\text { Accepted: } \\
\text { 22 February } 2017 \\
\text { Available Online: } \\
10 \text { March } 2017\end{array}$ & \\
\hline
\end{tabular}

\section{Introduction}

Along the flow path, Rivers transport water, sediments, organic materials and nutrients to the large terrestrial areas downstream. Due to this, transitions in biological communities and patterns of geochemical cycles from headwater streams to lowland stretches are manifested. Many research has been done on river microbiology which states that shifts in microbial community composition can be influenced by seasonal fluctuations in water flow, temperature, nutrient load etc (Kaevska et al., 2016; Shanmugam et al., 2016). Additionally, Individual bacterial populations can differ sturdily in their response to nutrient availability, sediment load as well as physical and chemical properties of water (Ma et al., 2016; Zhang et al., 2012).
Many research has been done on drinking water (Tyagi et al., 2015), biofilms from water distribution systems, waste water, fecal contamination and anthropogenic activities on river water quality(Korajkic et al., 2015; Musyoki, Suleiman, Mbithi and Maingi, 2013; Tyagi et al., 2015; Ye and Zhang, 2013). However, relatively fewer studies focused on bacterial community structure of the river basins.

Tapi River plays important and significant role in the development of Surat city. The mainstream of the Tapi River is $724 \mathrm{~km}$ long and flows through different cities as well as agricultural areas of Madhya Pradesh, Maharashtra and Gujarat. Many industries are 
located on the belt of river which are contributing to pollute the river water. Therefore, investigation was done get insights of the seasonal variability of the bacterial community composition of the river by taking into consideration the impact of pollutants added to river.

\section{Materials and Methods}

Water samples were collected from three different sites along the stretch of Tapi River. Selected sites for the study were; 1) Galteshwar as a reference site as it has least interference of human activities, 2) Utran as a site having sewage of the urban area and waste from the thermal power station as a pollution sources and 3) Ashwanikumar as a site under the influence of pollution from cremation ground.

The samples were collected in sterile containers and transported to laboratory for further analysis. The physico-chemical parameters such as $\mathrm{pH}$, temperature, Dissolved Oxygen, Nitrate and Phosphate of water samples were measured using standard methods of APHA, 2005. $\mathrm{pH}$ and Temperature were recorded and dissolved oxygen was fixed at the site itself.

For bacteriological studies, a serial dilution of each sample was made and $0.1 \mathrm{ml}$ of each diluted samples was plated onto nutrient agar (Hi Media) plates to determine Total Viable Count (TVC). The results were expressed in term of Colony Forming Unit (CFU) per unit volume $(\mathrm{mL})$, enumerated after $48 \mathrm{~h}$ of incubation. Depending on the variations in colony morphology or colony characteristics, the isolates were separated and stored on nutrient agar slants at $4^{\circ} \mathrm{C}$ for further analysis.

The isolates were identified by using standard morphological, cultural, biochemical and physiological characteristics as per the
Bergey's Manual of Determinative Bacteriology.

\section{Results and Discussion}

Values of various water quality parameters recorded during the study period are shown in table 1 .

During study period, highest temperature was 28.3 in summer and lowest temperature was 20.9 in winter. $\mathrm{pH}$ remain alkaline throughout the study period. Dissolved Oxygen was recorded lower during summer and comparatively higher during monsoon. Concentration of nutrients was recorded higher in summer as compare to other seasons.

Total viable count of the sample was analyzed and collected data are represented in table 2. The integrated values for bacterial enumeration indicate that higher bacterial load was observed during summer while during monsoon, lowest bacterial load was recorded. From three selected sites, bacterial load was consistently higher at downstream site i.e. Utran and lower at the upstream site i.e. Galteshwar.

Data of Identified bacterial genera in different seasons is represented in table 3. According to that, collectively in all seasons, total of 19 different bacterial genera were found. It is observed that the core composition of bacterial communities is consisting of Gammaproteobacteria, Firmicutes, Cyanobacteria, Bacteriodetes and Actinobacteria in which Gammaproteobacteria was reported as the most dominant group with families Enterobacteriaceae, Pseudomonadaceae, Vibrionaceae and Moraxellaceae at all the sampling sites. At Galteshwar which is selected as reference site, Flavobacterium sp. was reported as the only member of 
Bacteroidetes with least abundance. Bacterial communities were more diverse in summer as compare to winter and monsoon may be because of higher nutrient levels and warm temperature. Pseudomonas sp., E. coli, Klebsiella sp., Acinetobacter sp., and Vibrio $s p$. were recorded throughout the study period.
The bacterial community composition at three sampling sites along the Tapi River stretch for three seasons was studied along with physicochemical properties of water. Overall bacterial community composition was significantly diverse at different sites in different seasons.

Table.1 Average values of water quality parameters at 3 sampling sites in different seasons (G: Sampling site at Galteshwer, U: Sampling site at Utran, Ak: Sampling site at Ashwanikumar.)

\begin{tabular}{|c|c|c|c|c|c|}
\hline $\begin{array}{l}\text { Sr. } \\
\text { No }\end{array}$ & Para-meters & Sites & Winter & $\begin{array}{c}\text { Summ } \\
\text { er }\end{array}$ & $\begin{array}{c}\text { Monsoo } \\
\mathbf{n}\end{array}$ \\
\hline \multirow[t]{3}{*}{1.} & \multirow{3}{*}{$\begin{array}{c}\text { Temp. } \\
\left({ }^{\circ} \mathrm{C}\right)\end{array}$} & $\bar{G}$ & 20.9 & 27.8 & 24.3 \\
\hline & & $\mathrm{U}$ & 21.1 & 28.1 & 24.9 \\
\hline & & $\mathrm{AK}$ & 21.3 & 28.3 & 24.6 \\
\hline \multirow[t]{3}{*}{2.} & \multirow[t]{3}{*}{ pH } & $\mathrm{G}$ & 7.46 & 7.59 & 7.78 \\
\hline & & $\mathrm{U}$ & 7.76 & 7.96 & 8.03 \\
\hline & & $\mathrm{AK}$ & 7.7 & 7.90 & 8.11 \\
\hline \multirow[t]{3}{*}{3.} & \multirow{3}{*}{$\begin{array}{c}\text { DO } \\
(\mathrm{mg} / \mathrm{L})\end{array}$} & $\mathrm{G}$ & 7.5225 & 7.024 & 8.105 \\
\hline & & $\mathrm{U}$ & 8375 & 6.4105 & 7.24 \\
\hline & & $\mathrm{AK}$ & 6.1275 & 6.2625 & 7.17 \\
\hline \multirow[t]{3}{*}{4.} & \multirow{3}{*}{$\begin{array}{c}\mathrm{NO}_{3} \\
(\mathrm{mg} / \mathrm{L})\end{array}$} & $\mathrm{G}$ & 2.35825 & 1.800 & 1.60925 \\
\hline & & $\mathrm{U}$ & 4.29325 & 5.827 & 3.788 \\
\hline & & AK & 5.627 & 4.510 & 4.9205 \\
\hline \multirow[t]{3}{*}{5.} & \multirow{3}{*}{$\begin{array}{c}\mathrm{NO}_{2} \\
(\mathrm{mg} / \mathrm{L})\end{array}$} & G & 0.02575 & 2.087 & 1.38575 \\
\hline & & $\mathrm{U}$ & 0.043 & 4.732 & 4.23075 \\
\hline & & $\mathrm{AK}$ & 0.04625 & 8.415 & 7.4695 \\
\hline \multirow[t]{3}{*}{6.} & \multirow{3}{*}{$\begin{array}{c}\mathrm{PO}_{4} \\
(\mathrm{mg} / \mathrm{L})\end{array}$} & G & 0.04575 & 3.074 & 0.08675 \\
\hline & & U & 0.5295 & 3.991 & 0.2335 \\
\hline & & $\mathrm{AK}$ & 0.37625 & 6.436 & 0.26725 \\
\hline
\end{tabular}

Table.2 Average values of Total Viable Count (TVC) of water from 3 sites in different seasons (G: Sampling site at Galteshwer, U: Sampling site at Utran, Ak: Sampling site at Ashwanikumar)

\begin{tabular}{|c|c|c|c|c|c|c|c|}
\hline Sr. No. & & Sites & winter & Summer & Monsoon & Max. & Min. \\
\hline & \multirow{3}{*}{$\begin{array}{c}\text { Water } \\
\text { (TVC) } \\
\text { CFU } / \mathrm{ml}\end{array}$} & G & $3.7 \times 10^{5}$ & $4.75 \times 10^{5}$ & $3.27 \times 10^{5}$ & \multirow{2}{*}{$\begin{array}{c}10.6 \times \\
10^{5} \\
(S u m\end{array}$} & $3.27 x$ \\
\hline & & $\mathbf{U}$ & $6.1 \times 10^{5}$ & $6.5 \times 10^{5}$ & $5.6 \times 10^{5}$ & & $10^{5}$ \\
\hline & & $\mathbf{A K}$ & $9.0 \times 10^{5}$ & $6 \times 10^{5}$ & $8.3 \times 10^{5}$ & $\begin{array}{l}(\text { Sum } \\
\text { mer })\end{array}$ & (Mons \\
\hline
\end{tabular}


Table.3 Genera isolated during different seasons at three different sites

\begin{tabular}{|c|c|c|c|}
\hline & G & $\mathbf{U}$ & AK \\
\hline \multirow{7}{*}{ Winter } & E. coli & E. coli & E. coli \\
\hline & Pseudomonas & pseudomonas & Pseudomonas \\
\hline & Acinetobacter & Pantoea & Pantoea \\
\hline & Bacillus & Shigella & \\
\hline & Vibrio & salmonella & \\
\hline & Oscillatoria & Enterobacter & \\
\hline & & Enterococci & \\
\hline \multirow{13}{*}{ Summer } & E. coli & E. coli & E. coli \\
\hline & Pseudomonas & pseudomonas & Pseudomonas \\
\hline & Klebsiella & Klebsiella & Klebsiella \\
\hline & Acinetobacter & Enterobacter & Acinetobacter \\
\hline & Azotobacter & streptococcus & Salmonella \\
\hline & Nostoc & Vibrio & Vibrio \\
\hline & Oscillatoria & Pantoea & Shigella \\
\hline & Bacillus & Enterococci & Staphylococcus \\
\hline & Staphylococcus & & \\
\hline & Flavobacterium & & \\
\hline & staphylococcus aureus & & \\
\hline & Vibrio & & \\
\hline & Citrobacter & & \\
\hline \multirow{5}{*}{ Monsoon } & E. coli & E. coli & E. coli \\
\hline & Pseudomonas & pseudomonas & Pseudomonas \\
\hline & Klebsiella & Klebsiella & Klebsiella \\
\hline & Citrobacter & Vibrio & Salmonella \\
\hline & Acinetobacter & & \\
\hline
\end{tabular}

Figure.1 Relative abundance of various bacterial groups in different seasons
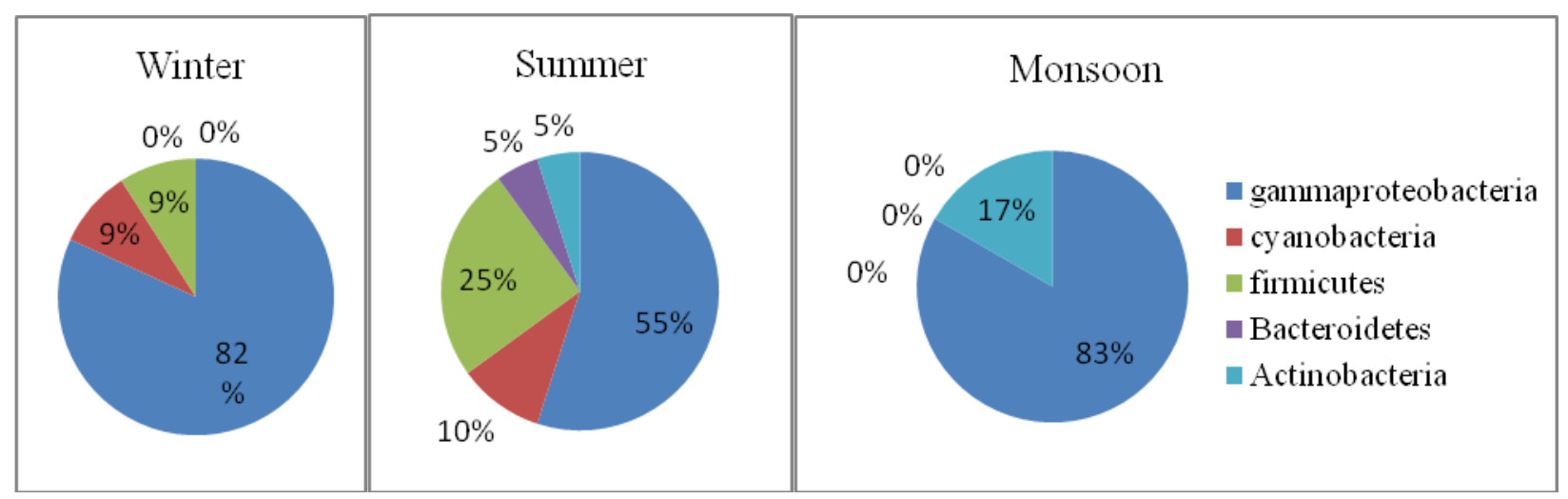
Bacterial communities seasonally changed in term of both diversity and abundance, with the difference in sources which may be agricultural or industrial runoff, sewage inlet, variation in water flow and drainage inlet from urban areas. Bacterial diversity was higher at upstream site of the river which may be due to the lack of disturbance and leas anthropogenic activities and at downstream diversity is lower under influence of various point and non-point pollution sources. On the contrary, bacterial abundance was recorded higher at downstream with some common genera and higher bacterial load.

Differences in bacterial load reported may be attributed to fluctuations in temperature and $\mathrm{pH}$. Various research groups have studied the seasonal influence on bacterial diversity and found that variations in temperature, $\mathrm{pH}$ and flow rate can have potential effect on the bacterial composition in river ecosystem (Bucci et al., 2014; Crump and Hobbie, 2005; Ma et al., 2016; Zhang et al., 2012).Concentration of nutrients also plays important role in determining the composition of bacterial communities and abundance. Research suggested that abundance of bacteria in freshwater ecosystem is related to the concentration of ammonia, nitrate and phosphate as they can cause eutrophication in freshwater and it affect the bacterial abundance as well as community structure (Kumari et al., 2011; Liu et al., 2013; Staley et al., 2015).

The consistent presence of coliform organisms as well as pathogens such as Klebsiella sp, E. coli, Citrobacter sp. etc. at the downstream sites indicates the fecal contamination that can result from the sewage inlets. Most abundant genera throughout study period was pseudomonas from the Gammaproteobacteria group which is omnipresent in freshwater environment and is having its importance because of its ability to degrade wide range of hydrocarbons as well as plastic (Das and Mukherjee, 2007; Swapnil et al., 2015).

On the whole, it can be concluded that Environmental factors, Physico-chemical properties, pollution and Interference of anthropogenic activities shape the bacterial community composition of the river. Results obtained can be implemented to understand how the bacterial communities respond to the environmental changes. Moreover, some of the pathogenic bacteria are also found in the water, presence of which must be taken into consideration for further research towards the removal of such pathogens before using the water for drinking purpose.

\section{Acknowledgement}

Authors are thankful to the head of department of aquatic biology, VNSGU for providing laboratory amenities to perform this work.

\section{References}

Bucci, J., Szempruch, A., Caldwell, J., Ellis, J., and Levine, J. 2014. Seasonal Changes in Microbial Community Structure in Freshwater Stream Sediment in a North Carolina River Basin. Diversity, 6(1): 1832. doi: https://doi.org/10.3390/d6010018

Crump, B.C., and Hobbie, J.E. 2005. Synchrony and seasonality in bacterioplankton communities of two temperate rivers. Limnol. Oceanography, 50(6): 17181729. https://doi.org/10.4319/lo.2005.50.6.1718

Das, K., and Mukherjee, A.K. 2007. Crude petroleum-oil biodegradation efficiency of Bacillus subtilis and Pseudomonas aeruginosa strains isolated from a petroleum-oil contaminated soil from North-East India. Biores. Technol., 98(7): 1339-1345. doi https://doi.org/10.1016/j.biortech.2006.05 .032 
Kaevska, M., Videnska, P., Sedlar, K., and Slana, I. 2016. Seasonal changes in microbial community composition in river water studied using 454pyrosequencing. Springer Plus, 5(1): 409. doi: https://doi.org/10.1186/s40064-0162043-6

Korajkic, A., Parfrey, L.W., McMinn, B.R., Baeza, Y.V., VanTeuren, W., Knight, R., and Shanks, O.C. 2015. Changes in bacterial and eukaryotic communities during sewage decomposition in Mississippi river water. Water Res., 69: 30-39.

doi: https://doi.org/10.1016/j.watres.2014.11.0 03

Kumari, V., Rathore, G., Chauhan, U.K., Pandey, A.K., and Lakra, W.S. 2011. Seasonal variations in abundance of nitrifying bacteria in fish pond ecosystem. J. Environ. Biol., 32(2): 153-9.

Ma, L., Mao, G., Liu, J., Gao, G., Zou, C., Bartlam, M. G., and Wang, Y. 2016. Spatial-temporal changes of bacterioplankton community along an exhorheic river. Frontiers in Microbiol., 7(MAR), 1-12. doi: https://doi.org/10.3389/fmicb.2016.00250

Musyoki, A.M., Suleiman, M. A., Mbithi, J. N., and Maingi, J. M. 2013. Diurnal and seasonal variations of pathogenic bacteria in Dandora Sewage Treatment Plant wastewater, Nairobi, Kenya. J. Res. Environ. Sci. Toxicol., 2(February), 3641.

Shanmugam, J., Ponnusamy, V., Gopal, M., and
Seshadri, S. 2016. Population Dynamics and Seasonal Variation of Bacterial System Utilizing Single Carbon from River Cooum and River Adyar, Chennai, Tamilnadu, India. Int. J. Curr. Microbiol. Appl. Sci., 5(3): 466-477. doi: https://doi.org/10.20546/ijcmas.2016.503. 055

Swapnil K. Kale, Amit G. Deshmukh, Mahendra S. Dudhare, V.B.P. 2015. Microbial degradation of plastic: a review. J. Biochem. Tech., 6(1): 952-961.

Tyagi, S., Singh, P., Sharma, B., Singh, R., Dobhal, R., and Uniyal, D.P. 2015. Bacteriological Assessment of Drinking Water Sources of Uttarakhand, India. Nat. Acad. Sci. Lett., 38(1): 37-44. doi: https://doi.org/10.1007/s40009-014-02868

Ye, L., and Zhang, T. 2013. Bacterial communities in different sections of a municipal wastewater treatment plant revealed by $16 \mathrm{~S}$ rDNA 454 pyrosequencing. Appl. Microbiol. Biotechnol., $\quad$ 97(6): 2681-2690. https://doi.org/10.1007/s00253-012-40824

Zhang, M., Yu, N., Liqiao, C., Jiang, C., Yanjie, T., Zhang, T., Xue, D. 2012. Structure and seasonal dynamics of bacterial communities in three urban rivers in China. Aquatic Sci., 74: 113-120. doi: https://doi.org/10.1007/s00027-011-0201$\mathrm{z}$.

\section{How to cite this article:}

Kinjal Sangani and Kapila Manoj. 2017. Seasonal Variations in Bacterial Community Composition in Tapi River, Surat, Gujarat, India. Int.J.Curr.Microbiol.App.Sci. 6(3): 1519-1524.

doi: https://doi.org/10.20546/ijcmas.2017.603.174 